\title{
The pattern of foreign property investment in Vietnam: the apartment market in Ho Chi Minh City
}

\section{Citation}

Jung, Sanghoon, Du Huynh, and Peter G. Rowe. 2013. The pattern of foreign property investment in Vietnam: the apartment market in Ho Chi Minh City. Habitat International 39: 105-113.

\section{Published Version}

doi:10.1016/j.habitatint.2012.11.003

\section{Permanent link}

http://nrs.harvard.edu/urn-3:HUL.InstRepos:10718414

\section{Terms of Use}

This article was downloaded from Harvard University's DASH repository, and is made available under the terms and conditions applicable to Other Posted Material, as set forth at http:// nrs.harvard.edu/urn-3:HUL.InstRepos:dash.current.terms-of-use\#LAA

\section{Share Your Story}

The Harvard community has made this article openly available.

Please share how this access benefits you. Submit a story.

Accessibility 


\title{
The Pattern of Foreign Property Investment in Vietnam: The Apartment Market in Ho Chi Minh City -
}

\author{
Sanghoon Jung*1, \\ Doctor of Design Candidate, \\ Department of Urban Planning and Design, \\ Graduate School of Design, Harvard University

\section{Du Huynh',} \\ Doctor of Design Candidate, \\ Department of Urban Planning and Design, \\ Graduate School of Design, Harvard University
}

\begin{abstract}
Peter G. Rowe ${ }^{3}$
Raymond Garbe Professor of Architecture and Urban Design and Harvard University

Distinguished Service Professor,

Department of Urban Planning and Design,

Graduate School of Design, Harvard University
\end{abstract}

\section{Paper submitted to Habitat International in 2012}

Department of Urban Planning and Design, Graduate School of Design, Harvard University 48 Quincy Street 325,

Cambridge, MA, 02138, U.S.A.

Tel: +1 917.548.5319

Fax: +1617.495 .0446$

Email: saj916@mail.harvard.edu, duhtvn@gmail.com, prowe@gsd.harvard.edu 


\title{
The Pattern of Foreign Property Investment in Vietnam: The Apartment Market in Ho Chi Minh City
}

\begin{abstract}
As globalization proceeds, transnational property development is increasing. Especially in emerging markets, foreign developers' influence in changing the local landscape is becoming significant. In this research, the behavioral patterns of foreign developers in the apartment market of Ho Chi Minh City, Vietnam were identified. To understand the dynamics of foreign developers, the types of products that were being created, where the investments were located, and the differences in development strategies adopted by foreign developers in comparison to domestic counterparts were identified. To accomplish this, data on apartment projects and statistics were collected, and a series of spatial analyses including sieve mapping, histogram analysis, factor analysis and logistic regression was conducted. In addition, closer examination was made of specific cases to understand the dynamics among foreign and domestic developers, also allowing the identification of some regularities in the patterns of foreign developments. Besides presenting detailed results, this paper also seeks to account for the conditions that appear to have generated these patterns and characteristics.
\end{abstract}

Keywords: Ho Chi Minh City, Foreign Investment, Investment Pattern, Apartment, Peri-urbanization

\section{Introduction}

As globalization proceeds, transnational property developments have increased significantly. The freer movement of capital, facilitated by deregulation, policy reforms, and a movement toward greater global trade integration, coupled with improvements in communication and transportation technology, developers from one country can readily implement projects in another. Especially in emerging markets, the influence of transnational investments in changing the local landscape is becoming more significant. Accordingly, there have been some researches on where foreign investments locate and why they chose to locate in those places when they entered the particular market. The locational patterns of finance and producer services by foreign investment have been especially studied for several cases. For example, Grant and Nijman investigated the geographic distribution of foreign companies in finance and producer services in Accra and Mumbai and found that market forces drove foreign companies to be spatially segregated from domestic counterparts within city centers (Grant, 2001; Grant \& Nijman, 2002). In the case of manufacturing ventures, Wei et al. argued that 
investment policies of the local government are the most important factor accounting for the locational behavior of foreign ventures in their investigation of Nanjing (Wei, Luo, \& Zhou, 2010), and the similar explanation also applied in Hangzhou (Wei, Leung, Li, \& Pan, 2008).

Compared to these sectors in which foreign investors typically have comparative financial and technical advantages over the local players, the housing markets in emerging economies are generally an exception, mainly because foreign companies are unable to penetrate the markets as easily as their domestic counterparts. Foreign companies may have more sophisticated construction techniques and access to finance, but domestic firms have the advantage of possessing a better understanding of the local residential culture, lifestyle, climate conditions and so on. They are also more competitive in terms of cost reduction, having a strong business network and a familiarity with the local legal process. Therefore, the tension between foreign and domestic companies is more likely to be conspicuous in the housing market, and a different approach is thus required to for its analysis.

However, the manner in which foreign property developers behave when they enter a new market, vis-à-vis their products and strategies with a focus on housing type, remains an under-studied area. While there have been substantial case studies (e.g. Chen, Wang, \& Kundu, 2009; Douglass \& Huang, 2007; Huat, 2011; Percival \& Waley, 2012; Shatkin, 2011) about the properties developed by foreign developers dealing with the driving forces and mechanism of investments in specific cases, spatial segregation from local environment and so on, quantitative evidences about how foreign developers' properties show different patterns from those developed by domestic counterparts have been rarely provided. Through an investigation of the growing apartment market in Ho Chi Minh City, Vietnam, into which substantial foreign real-estate investment have been channeled recently, this study intends to identify how foreign developers are different from their domestic counterparts in terms of where they locate their investments, how their products are different in terms of sizes and price, and how their strategies are different.

\section{Foreign Investment and the Apartment Market in Vietnam}

Since Doi Moi (open door policy) in 1986, Vietnam has become a destination for foreign investment business by multinationals. Over the past decade, annual GDP growth has averaged 7.2\%. With increasing integration into the global economy, 'Foreign Direct Investment' (FDI) into Vietnam has also surged. Net inflows of FDI ranged between \$1.3 billion and \$1.8 billion in 2002-2006 and soared to \$6.6 billion in 2007 and \$9.3 billion in 2008 (Anwar \& Nguyen, 2010; Asian Development Bank, 2009). For firms pursuing a "China-plus-one" strategy for new factories in case things go awry in China, for example, Vietnam often turns out to be the "plus-one" (The Economist, 2008). In this regard, a large proportion of FDI originates from East Asian countries such as Korea, Taiwan and Singapore (See Fig. 1). 
Since Doi Moi (open door policy) in 1986, Vietnam has become a destination for foreign investment business by multinationals. Over the past decade, annual GDP growth has averaged 7.2\%. With increasing integration into the global economy, 'Foreign Direct Investment' (FDI) into Vietnam has also surged. Net inflows of FDI ranged between \$1.3 billion and \$1.8 billion in 2002e2006 and soared to $\$ 6.6$ billion in 2007 and $\$ 9.3$ billion in 2008 (Anwar \& Nguyen, 2010; Asian Development Bank, 2009). For firms pursuing a "China-plus-one" strategy for new factories in case things go awry in China, for example, Vietnam often turns out to be the "plus-one" (The Economist, 2008). In this regard, a large proportion of FDI originates from East Asian countries such as Korea, Taiwan and Singapore (see Fig. 1).

Not surprisingly, economic growth has changed the urban landscape of Vietnam substantially. The level of urbanization has grown from 19\% in 1984 to an estimated 27\% in 2007 (McGee, 2009: p. 230). A significant proportion of this urban population is centered on the three major urban centers of coastal Vietnam that include Hanoi-Haiphong in the Red River Delta, Ho Chi Minh-Binh DuongDong Nai-Vung Tau on the edge of the Mekong Delta and the central costal region around Da-Nang. Ho Chi Minh City (HCMC), in particular, has been a strong engine of the economic growth (Dapice, Gomez-Inanez, \& Thanh, 2010: p. 2). The mega-urban region centered there recently accounted for 52\% of the total FDI received and 74\% of all investment (McGee, 2009: p. 230). Further, the apartment market of HCMC plays a significant role in attracting FDI. According to 'Property Report,' foreigners have been buying into apartments in HCMC for some time and at an astonishing rate. Around 85 percent of FDI that found itsway into the city during 2007 flowed directly into the property sector. HCMC attracted US\$2.5 billion during that period with over US\$2.1 billion going into real estate."

\section{'INSERT FIG. 1 AROUND HERE'}

There are mainly three urban housing typologies in Vietnam: villas, row houses and apartments (Ly, Birkeland, \& Demirbilek, 2010). Among them, apartments are not the housing type local people prefer. In an interview with Nguyen Trong Hoa, Head of 'Ho Chi Minh City Institute for Development Studies' (HIDS), he explained the reason as follows.

There are some reasons why Vietnamese prefer villas to apartments. The first is that Vietnam originally was an agricultural country. Only about 20 years ago, more than $90 \%$ of the population was composed of farmers, and for farmers, having the land is very important. Therefore, when farmers migrate to the city, they still consider land as an indispensable asset. Second, in Vietnam we haven't established industrial manners quite yet. By industrial manners I mean the division of labor in an urban city. Life in the countryside is mostly self-sufficient, but when they come to the city, there is labor division, and other people take care of electricity, garbage disposal, etc. But because they were farmers, they want to do everything on their own, they want to dig their own wells, generate their own electricity, dispose of 
their own garbage. This means, the industrialization in Vietnam is too fast, while the people have difficulty in keeping up with the change. Urban civilization is not established yet. Moreover, the public service is quite bad. If electricity is cut, people have to walk many floors and carry water manually. Thus until now, this bad impression about apartments is still engraved in people's mind. (Hoa, 2011)

In other words, agricultural customs, difficulty adapting to urban lifestyles and doubts about public services make people hesitate to live in urban apartments. However, there have been some changes in this orientation. Apartment price, for instance, has risen in the mid-2000s, despite recent contraction. According to Hoa, consumers of apartments are mostly foreigners and young people who have lived in other countries (Hoa, 2011). Since most foreign investment into Vietnam is from East Asia, the majority of foreigners are also from East Asia and their lifestyle is well fitted to apartment living. As a result of such changes, apartments are also increasingly inhabited by members of the upper middle class. Fig. 2 shows the rough relationship between housing type and income level. It shows the wealthiest people live in villas, although apartments are usually consumed by households whose income per month is over 7 million Vietnamese Dong (VND).

\section{'INSERT FIG. 2 AROUND HERE'}

Following on from this, apartments are more suitable for foreign developers to develop for several reasons. First, it is harder for foreigners to obtain land, and, therefore, apartments are better for them to make a profit from small areas of land. Second, since their information is limited compared to locals, it is better to focus on a small number of large-scale projects than on a large number of smallscale projects. Moreover, as seen in Fig. 1, most foreign developers in Vietnam are from East Asia, especially from Taiwan, Korea, Japan, and Singapore. Since apartments are what are frequently developed there, their human resources and expertise are accustomed to the development of this housing type.

\section{Data and Methodology}

The main methodologies used in this study are logistic regression and factor analysis. Since the main objective of this study is to discover behavioral patterns of foreign investment which are different from the local, a dependent variable was set as to whether each project was developed by foreign developer or not. In many cases, foreign developers' projects were implemented as joint ventures in conjunction with a local partner. Until recently, this formation was the only way for foreigners to invest in property development since foreigners' ownership of land-use rights was legally prohibited until 2009. In the joint venture setting in Vietnam, local partners, mostly state- 
owned enterprises, often contributed land as their share in investment, while the foreign partner usually played the more active part in project development (Kim, 2008: p. 46). Therefore, apartment projects developed by joint ventures were also categorized in a binary fashion as being developed by foreign developers. Statistically, this allowed logistic regression to be conducted. Then, factor analysis was employed to sort out correlated variables into a potentially lower number of uncorrelated factors.

The boundary of analysis is shown in Fig. 3 and includes the downtown and newly developed areas of districts 2, 7 and 9 where many foreign-developed apartments are located. To avoid selection bias, all the data categorized as 'apartments' (căn hộ) inside the boundary were included. Fully, 180 projects (139 by domestic and 41 by foreign developers) were appraised. The data set was then examined by Vietnamese local real-estate professionals. Apartment project data employed in this study was obtained from the Vietnamese local real-estate websites, which included Mua bán nhà đất (http://muabannhadat.com.vn/). The available data in the websites was comprised of unit area, price per square meter and the location of each project. Minimum and maximum values in unit area and price per square meter were selected as independent variables. Travel time to downtown was also selected as an independent variable in order to understand the location of apartments developed by foreign developers vis-à-vis accessibility to downtown. In HCMC, downtown is still the center of most urban activities, dealing with commerce and business, and accessibility to downtown is of considerable importance when deciding where to live. To understand the locational characteristics of each project, travel time to premier schools, hospitals, factories, theaters and restaurants were also included in the analysis. In addition, elevation was included to measure the flooding risk. To calculate these variables and conduct spatial analysis, a GIS model of HCMC was created based on Google Earth.

\section{'INSERT FIG. 3 AROUND HERE'}

Because the demographic feature of location plays an important role in decision making, 'population growth rate' and 'population density' were also chosen as independent variables. The population data of HCMC was derived from the Ho Chi Minh City Bureau of Statistics (Ho Chi Minh City Department of Statistics, 2010). Since population data by wards was only available for 2008 and the district data was available for every year, the population density was calculated at the ward level and population growth rate at the district level. To understand the local characteristics of the location of each project, other district data such as the 'revenue of district budget,' 'non-state industrial output value,' 'industrial output value of the household economic sector,' 'the number of household trade, hotel, restaurant \& services,' 'number of schools of general education,' and 'number of pupils per teacher' were extracted from Ho Chi Minh City statistical yearbook and included in the analysis. These input variables turned out to be correlated to each other. For example, travel time to downtown 
is highly correlated to travel time to premier schools, hospitals, theaters and restaurants, as well as with population density. To resolve this issue, factor analysis (principal components) was used to sort out independent variables into fewer factors. The factor values resulting from factor analysis were then substituted into the logistic regression model. Assuming $k$ as number of factors and $n$ as number of independent variables, the general form of the regression model is expressed as the following equation.

$$
\ln \left(\frac{p i}{1-p i}\right)=\alpha+\beta_{1} F_{1}+\beta_{2} F_{2}+\beta_{3} F_{3}+\ldots \ldots+\beta_{k} F_{k}+u
$$

where $p_{i}$ is the probability of each apartment's being developed by foreign developer or not, and $F_{k}$ is the factor value of the $k$ th factor. The independent variables are converted into factors by following equation.

$$
F_{k}=W_{k 1} x_{1}+W_{k 2} x_{2}+W_{k 3} x_{3}+\ldots \ldots+W_{k n} x_{\mathrm{n}}
$$

where $x_{k}$ is $k$ th variable and $W_{k \text { n }}$ denotes the factor score coefficients which are used to convert the influence of independent variables $\left(x_{k}\right)$ into factor values $F_{k}$. The correlation coefficients between variables and factors are also expressed in another way, which follows.

$$
x_{i}=l_{i 1} F_{1}+l_{i 2} F_{2}+l_{i 3} F_{3}+\ldots \ldots+l_{i k} F_{k}
$$

where $l_{i k}$ coefficients are called the factor loadings (See Table 1). These coefficients explain the extent to which each factor contributes to each variable.

In addition, in-depth interviews with Vietnamese governmental officials and foreign developers were conducted during a fieldtrip to understand the driving forces of decisions made by foreign developers. The characteristics of the apartment market in HCMC and perceptions of local people about apartment living were also identified. Further, the decision making processes of foreign developers were investigated through a series of in-depth interviews.

\section{Result and Analysis}

\section{Mapping}

As shown in Fig. 4, foreign developers' property developments tend to locate on the periphery of the city and are formed in clusters. The overall locations of foreign-developed apartments are neither 
too far away nor too close to downtown. This trend can be also applied to measures of 'unit area' and 'price per square meter.' Looking at the histograms shown in Fig. 5, foreign developers seem to cluster in a certain range of unit area, price and distance from city center, while domestic developers' range across the three variables is comparably diverse.

\section{'INSERT FIG. 4 AROUND HERE'}

\section{'INSERT FIG. 5 AROUND HERE'}

Considering a combination of median price and developer type, as exhibited in Fig. 4, the apartment market of Ho Chi Minh City can be classified into three categories. The first is high-priced apartments in downtown, mostly developed by domestic developers. As shown in Fig. 5, there exist very few foreign developer projects in downtown, but apartment price there is the highest. The second is a set of clusters of high-priced apartments on the periphery developed by foreign developers. Mostly located in district 2 and 7, foreign developers tend to cluster together and their pricing is higher than neighboring domestic projects. The third is in between these two categories, which consists of domestic low-priced projects.

\section{Factor Analysis}

In order to analyze the characteristics of foreign developers' location and product, a series of quantitative analyses were conducted on relevant data set. First, factor analysis was conducted to sort out correlated input variables. In short, factor analysis is designed to describe variability among a set of observations of possibly correlated variables into a potentially lower number of uncorrelated variables called factors. The results are displayed in tables 1 and 2.

Table 2 shows that about 84 percent of the variation in the original data is explained by factors $1 \mathrm{e} 6$. Further, since the share of each of the factors $7 \mathrm{e} 21$ is small, emphasis will be placed here on factors 1e6. As shown in Table 1, factor 1 has high positive loadings with regard to travel time to downtown, premier schools, hospitals, theaters and restaurants, and high negative loadings with regard to population density. Since most of premier schools, hospitals, theaters and restaurants are concentrated in downtown, factor 1 seems to have high correlation with location. In addition, the population density is generally higher near downtown and decreases as it expands toward the periphery as shown in Fig. 3. Thus, factor 1 can be called the 'Accessibility factor.' As it goes further away from downtown to periphery, this factor also tends to increase. Factor 2 has high positive loadings on price variables, and can be called the 'Price factor.' Factor 3 has high positive loadings on 'the revenue of district budget,' 'non-state industrial output value,' 'the number of household trade, hotel, restaurant $\&$ services,' and 'the number of schools of general education,' and high negative loadings on 'the 
number of pupils per teacher.' Since all of these are district-level data, factor 3 essentially describes levels of local public service and can be referred to as the 'Local Public Service factor.' If the level of public service in the region increases, factor 3 increases. Factor 4 has high positive loadings on 'travel time to factory' and 'population growth rate.' Since factories are potential sites for employment and population growth rate is an important measure for growth potential, it can be called 'Growth Potential factor.' Similarly, factor 5 has high positive loadings on unit area, and can be called 'Unit Area factor.' Finally, factor 6 has high positive loadings on 'elevation,' 'travel time to water,' and 'industrial output value of household economic sector,' and can be referred to as the 'Water proximity factor.'

Table 1. Loadings of Factor Analysis

\begin{tabular}{|c|c|c|c|c|c|c|}
\hline Variable & $\begin{array}{c}\text { Factor1 } \\
\text { Accessibil } \\
\text { ity }\end{array}$ & $\begin{array}{c}\text { Factor2 } \\
\text { Price }\end{array}$ & $\begin{array}{l}\text { Factor3 } \\
\\
\text { Local } \\
\text { Public } \\
\text { Service } \\
\end{array}$ & $\begin{array}{c}\text { Factor4 } \\
\text { Growth } \\
\text { Potential }\end{array}$ & $\begin{array}{l}\text { Factor5 } \\
\text { Unit Area }\end{array}$ & $\begin{array}{c}\text { Factor6 } \\
\\
\text { Water } \\
\text { Proximity }\end{array}$ \\
\hline \multicolumn{7}{|l|}{ Project Data } \\
\hline Travel Time to downtown & 0.8638 & -0.2844 & -0.0327 & 0.2881 & 0.0658 & 0.1778 \\
\hline Unit Area_Minimum & 0.1323 & 0.1245 & 0.0906 & 0.2137 & 0.7088 & -0.0146 \\
\hline Unit Area_Maximum & 0.0870 & 0.1713 & 0.0167 & -0.0003 & 0.8978 & -0.0318 \\
\hline Unit Area_Median & 0.1143 & 0.1792 & 0.0439 & 0.0718 & 0.9582 & -0.0304 \\
\hline Price per sqm_Minimum & $\begin{array}{ll}-0.2809 \\
\end{array}$ & 0.8652 & 0.2105 & -0.1316 & 0.1721 & 0.0601 \\
\hline Price per sqm_Maximum & -0.2657 & 0.8658 & 0.1776 & -0.1035 & 0.2239 & 0.0022 \\
\hline Price per sqm_Median & -0.2752 & 0.8736 & 0.1944 & -0.1174 & 0.2021 & 0.0289 \\
\hline Elevation & \begin{tabular}{ll|}
-0.1584 \\
\end{tabular} & 0.4561 & 0.1315 & -0.1363 & -0.1761 & 0.6716 \\
\hline Travel Time to Water & 0.5670 & 0.0400 & -0.0661 & -0.1654 & -0.0771 & 0.6685 \\
\hline Travel Time to Premier School & 0.8919 & -0.1510 & -0.0749 & -0.0144 & 0.0373 & -0.1185 \\
\hline Travel Time to Hospital & 0.8944 & -0.1938 & -0.1062 & -0.2631 & 0.0683 & -0.0259 \\
\hline Travel Time to Factory & 0.4454 & -0.1495 & -0.0185 & 0.7310 & 0.0398 & 0.0815 \\
\hline Travel Time to Theater & 0.8666 & -0.2261 & -0.0427 & 0.3685 & 0.1219 & -0.0242 \\
\hline Travel Time to Restaurant & 0.9042 & -0.1246 & -0.0724 & 0.3178 & 0.1002 & -0.1038 \\
\hline \multicolumn{7}{|l|}{ Ward Data } \\
\hline Population Density & \begin{tabular}{|l|l|}
-0.5998 \\
\end{tabular} & -0.2643 & -0.0155 & -0.4295 & -0.1226 & 0.0775 \\
\hline \multicolumn{7}{|l|}{ District Data } \\
\hline Population Growth Rate & 0733 & -0.1284 & -0.1625 & .9028 & 0.1523 & -0.1760 \\
\hline $\begin{array}{l}\text { Revenue of District Budg } \\
\text { by population) }\end{array}$ & -0.0125 & 0.5165 & 0.6771 & 0.0925 & 0.0716 & -0.2723 \\
\hline $\begin{array}{l}\text { Non-State Industrial Output Value } \\
\text { (divided by population) }\end{array}$ & -0.2905 & -0.4076 & 0.5329 & -0.0662 & 0.0405 & 0.5000 \\
\hline $\begin{array}{l}\text { Industrial output value of household } \\
\text { economic sector (divided by } \\
\text { population) }\end{array}$ & -0.3629 & -0.4111 & -0.2123 & -0.0298 & 0.1453 & 0.5377 \\
\hline $\begin{array}{l}\text { Number of household trade, hotel, } \\
\text { restaurant \& services per } 10 \mathrm{k} \mathrm{ppl}\end{array}$ & 51 & 88 & 352 & 0.0369 & 0.0411 & 0.0120 \\
\hline $\begin{array}{l}\text { Number of Schools of General } \\
\text { education per } 10 \mathrm{k} \mathrm{ppl}\end{array}$ & -0.1964 & 0.2284 & 0.7506 & -0.4931 & 0.0595 & 0.0546 \\
\hline Number of Pupils per teacher & 0.2888 & -0.1822 & -0.6253 & 0.4859 & -0.0334 & -0.1337 \\
\hline
\end{tabular}

*Loadings higher than 0.53 are highlighted 
Table 2. Variance explained by Factor Analysis

\begin{tabular}{l|r|r|r|r}
\hline Factor & Eigenvalue & Difference & Proportion & Cumulative \\
\hline \hline Factor1 & 7.42463 & 3.32973 & 0.3375 & 0.3375 \\
\hline Factor2 & 4.09489 & 1.65668 & 0.1861 & 0.5236 \\
\hline Factor3 & 2.43821 & 0.69277 & 0.1108 & 0.6344 \\
\hline Factor4 & 1.74544 & 0.31895 & 0.0793 & 0.7138 \\
\hline Factor5 & 1.42649 & 0.16187 & 0.0648 & 0.7786 \\
\hline Factor6 & 1.26461 & 0.53173 & 0.0575 & 0.8361 \\
\hline
\end{tabular}

\section{Logistic Analysis}

With these six factors, logistic regression analysis was conducted vis-à-vis the binary variable of whether each project was developed by foreigners or not, which can also be classified as the 'Foreign' variable. Table 3 shows that the all six factors are highly statistically significant in explaining the 'Foreign' variable.

Table 3. Logistic Regression with 'Foreign' variable

\begin{tabular}{ll|r|r|r|r}
\hline FOREIGN & Coef. & Std.Err. & $\mathrm{z}$ & $\mathrm{P}>|\mathrm{z}|$ \\
\hline \hline Factor1 (Accessibility) & 2.132076 & 0.5609672 & 3.80 & 0 \\
\hline Factor2 (Price) & 2.500576 & 0.5739347 & 4.36 & 0 \\
\hline Factor3 (Local Public Service) & -3.074182 & 0.7682544 & -4.00 & 0 \\
\hline Factor4 (Growth Potential) & 1.729068 & 0.3208078 & 5.39 & 0 \\
\hline Factor5 (Unit Area) & 0.9942375 & 0.2804883 & 3.54 & 0 \\
\hline Factor6 (Water proximity) & -2.143345 & 0.702673 & -3.05 & 0.002 \\
\hline cons & -3.8669 & 0.7030511 & -5.50 & 0 \\
\hline
\end{tabular}

According to this logistic analysis, as development goes out to the periphery, the probability of being developed by foreign developers increases. When it comes to price, price level is higher in foreign-developed properties. The result of factors 3 and 4 shows that foreign developers tend to locate where the level of public service is lower but the growth potential is high. Since their political power and social network (which is crucial in HCMC) is low, they tend to locate where public services are comparably not sufficient, but in the new land where growth potential is high. As factor 6 results show, these locations are in lower elevations and close to water, and where the informal economy is relatively strong. Since HCMC is located in a delta region, there is little hilly area in the city and flooding occurs frequently. Therefore, higher elevation is usually better for building properties. Meanwhile, closeness to rivers is preferred in the local real-estate market. Many of the 
names of properties close to rivers include the term 'river,' i.e. River park, Riverside and so forth. Since lower elevation is highly correlated to better accessibility to water, the distance to a river is somewhat contradictory to the property value. The regression result shows that foreign developers tend to locate near water, although with more risks to flooding. These results so far also correspond to findings from interview with a Korean developer, such as the following.

Since the level of public service is low in the locations where we are located, we have to provide decent services within the complex. To provide such services, the new property's density should be high; otherwise the price level would be way high.

In sum, the logistic regression results show that foreign developers tend to locate their investment on the periphery of the city and their products tend to be bigger and pricier than domestic counterparts. The level of local public service is lower, the area is susceptible to flooding risk, the informal sector is bigger, but growth potential is high. They are thus also urged to create new value because of these worse conditions than those under domestic development.

\section{Case Studies: District 2 and 7}

In order to understand more detailed behavioral patterns of foreign and domestic developers, additional investigation was conducted on districts 2 and 7, where foreign developers are concentrated. First, in the case of district 7, Phu My Hung (PMH) is where foreign developers are intensively located. Originally a swamp area $7 \mathrm{~km}$ from the downtown of HCMC, PMH is part of a larger scheme of HCMC to develop south of the city. The Central Trading \& Development Group (CT\&D), a Taiwanese company and the city government cooperated in the development of the Tan Thuan export processing zone (EPZ) and PMH (Ngo \& Huynh, 2010; Waibel, 2004). For the development of EPZ, the city government established Industrial Promotion Corporation (IPC) to venture with CT\&D. In turn, Phu My Hung Corporation, which was established between CT\&D on Taiwanese side and IPC on the behalf of the city government, initiated and took control of PMH development.

After the joint venture began its development from the mid-1990s, domestic developers followed. Since they could not find land inside the PMH area, they located in the vicinity to benefit from the readily increased value of this area. Figs. 6 and 7 shows, respectively, the developments by foreign developers inside Phu My Hung and the clustering of apartments by domestic developers in the vicinity of Phu My Hung. The cranes in Fig. 7 imply that the domestic developers' projects are comparably new while many of foreign developers' properties are already built. In terms of price and quality, domestic developers are cheaper, with worse but still decent quality. In addition, another new town project by a Korean developer is being developed south of Nha Be district. In short, the general 
pattern of apartment developments in district 7 is that the Taiwanese developers first pioneered on the urban periphery, followed by domestic and other foreign developers (Fig. 8).

'INSERT FIG. 6 AROUND HERE'

'INSERT FIG. 7 AROUND HERE'

Another cluster of foreign developers is located in district 2. Success of Taiwanese developers in district 7 attracted other foreign developers mostly from Singapore and Korea into Ho Chi Minh City. However, since district 7 was already well occupied by the Taiwanese, they located in district 2, which has similar conditions to those in district 7 . This area is well connected to the downtown via a highway and was underdeveloped as in district 7. As in district 7, foreign developers' products are more expensive and with better quality than domestic developers'. However, this area shows not much difference in completion years between foreign and domestic developers. In this regard, it is different from district 7. In short, Phu My Hung's development was a lesson for domestic developers and other foreign developers. Witnessing the sudden changes in land value on the periphery, they chose to go outside its boundaries.

\section{'INSERT FIG. 8 AROUND HERE'}

These two clusters show differences in decision making for location. In case of district 7, the decision maker for the location is relatively unclear. Even though the development is part of the city government's larger plan to develop south of the city, Taiwanese developer played a leading role in the project implementation and financing. According to Tran Tri Vo, then the Secretary of the city government, while the initiative to build Tan Thuan EPZ was originated from Vietnam, the idea of PMH was the initiative of Lawrence S. Ting, then the CEO of CT\&D and Phan Chanh Duong, then the CEO of IPC (Vo, 2005). In addition, individual developer decided where to invest. Therefore, the pattern of foreign investments in district 7 was driven not entirely by state intervention or market forces. On the other hand, the decision making of foreign developers in district 2 is more involved with market forces. The city government's master plans for this area also exist, but individual developers' decisions on their investment location were more driven by market analysis and forces.

\section{Conclusion}

Why does this phenomenon happen? In terms of the accessibility factor, it is better for foreign developers to locate their investment on the periphery and cluster together. For the foreign developers, 
land acquisition is a big obstacle in their business. The land near downtown is more complicated in terms of politics, property right and local economics. Since foreign developers only have superficial knowledge about how the local real-estate market works, investing near downtown imposes more risks. Therefore, it is better for them to invest in newly-developed areas, where growth potential is high and ownership is less complicated, and where new value can be readily created. These decisions in a group, in turn, intensify the peri-urbanization. As the analysis so far clearly shows, the tendency to go outside is more intensive in foreign developers in comparison to domestic counterparts.

In terms of Price and Unit Area factors, the results clearly show that foreign developers' apartments are bigger in both unit size and price per square meter. If these two features are both high, the price for each apartment unit will be much higher than those of domestic developers. Further, it is difficult for the foreign developers to compete with their domestic counterparts in terms of price on their home ground with advantages of business information, social networks, and political connections. As similar to other third world cities, political connections and social networks are key factors for successful business in HCMC (Kim, 2008: 32-34). Even though HCMC's government is comparably cooperative with private business and its social networks are open to new entrants, compared to other regions in Vietnam (Kim, 2008: 50), foreign developers' network is still inferior to domestic developers. It also applies to legal process. With exception of PMH development where special government arrangement for the project approval and permits in the southern portion of the city was established, most foreign developers suffer from difficulties in legal process (Kim, 2008: 77).

As a result, both the Local Public Service and Water proximity factors reveal that foreign developers tend to locate where current conditions are poorer than the location of domestic projects. To address flooding risk, they also construct dikes and advertise their properties as waterfront properties. To overcome the lack of public services, they tend to build a complex of high-rise apartments which can also accommodate comprehensive services for residents. To overcome such disadvantages, foreign developers seem to target their products to different market segments and tend to develop more luxurious apartments with bigger unit sizes and prices, as Price and Unit Area factors show.

Looking into specific cases, it was also found that the general pattern of developments towards the periphery is led by foreign developers who pioneer into generally more unfavorable wetlands, such as in district 7, and then domestic developers follow, building apartments with cheaper prices although decent quality in the vicinity of the foreign pioneers. Other foreign developers also joined this process and settled themselves in another area (district 2) with similar conditions to district 7 . In terms of price and quality, however, they still adhere to high-quality apartments with high prices.

These patterns are somewhat different from the locational patterns of other sectors such as finance and producer services or manufacturing industries. For finance and producer services, foreign companies are segregated from domestic counterparts, but they are typically still located inside the 
city center, while the local government's policies are most influential in the locational patterns of manufacturing industries. The locational pattern of foreign property developments in the housing market is influenced by both of market forces and government's policies. In case of district 7, PMH was a part of a larger scheme of the HCMC government, but the individual investment decisions were made by foreign joint venture. In district 2 , the decision was more influenced by market forces.

Even though globalization proceeds, foreign developers are foreign, after all. Due to a comparative lack of social network and understanding of local market, as well as disadvantages in other elements such as cost reduction, they are driven to locate further from existing urban areas, clustering together and, in turn, creating new values from areas with poor conditions. Even after all these obstacles, another one awaits. The local public opinion and politics are not hospitable to foreign investors' making substantial profit. In case of $\mathrm{PMH}$, public opponents complained that foreign investors had made too much profit, and the tax policy was changed for the government to take more money from the development (Ngo \& Huynh, 2010: 16-17).

The sustainability of this pattern should also be considered. In a situation that FDI is increasingly channeled into property development in Vietnam, this investment pattern facilitates the decline in urban center and peri-urbanization. To preserve the activity and environment of urban center, the property title should be clearer and more transparent legal procedure should be prepared. When it comes to the urban expansion, the developments should be properly managed to avoid sprawl. The relevant infrastructure and other public services should be also properly provided.

Could this pattern in Ho Chi Minh City also apply in other cities in Vietnam, or other countries? The tension between foreign and domestic companies is likely to vary according to each country's business culture, governmental policies, and so on. The differences in legal system and environment may result in different pattern of foreign property investment in each country. On the other hand, the complicated property right in the urban center and foreign developers' lack of social network is commonly observed in many emerging markets. Therefore, this kind of pattern may also happen in many other countries. In order to address this question, further case studies and comparative researches will be required.

\section{References}

Anwar, S. \& Nguyen L.P. (2010). Foreign direct investment and economic growth in Vietnam. Asia Pacific Business Review, 16(1), 183-202.

'A Special Report on Vietnam: Half-way from rags to riches', The Economist, April 24, 2008

Asian Development Bank. (2009). Asian Development Bank and Vietnam: Fact sheet.

Chen, X. M., Wang, L. \& Kundu, R. (2009). Localizing the Production of Global Cities: a Comparison of New 
Town Developments around Shanghai and Kolkata. City \& Community, 8, 433-465.

Dapice, D., Gomez-Inanez, J.A. \& Thanh, N.X. (2010). Ho Chi Minh City: The Challenges of Growth. Vietnam Programme, Ash Center for Democratic Governance and Innovation at the Harvard Kennedy School. UNDP-Harvard Policy Dialogue Paper Number 2. Ho Chi Minh City: United Nations Development Programme

Douglass, M. \& Huang, L. (2007). Globalizing the city in Southeast Asia: utopia and the urban edge - the case of Phu My Hung, Saigon. International Journal of Asia-Pacific Studies, 3(2), 1-42.

Grant, R. (2001). Liberalization Policies and Foreign Companies in Accra, Ghana. Environment and Planning A, $33,997-1014$.

Grant, R. \& Nijman J. (2002). Globalization and the Corporate Geography of Cities in the Less-Developed World. Annals of the Association of American Geographers, 92(2), 320-340.

Hoa, Nguyen Trong. Interview by author, August 2, 2011.

Ho Chi Minh City. Department of Statistics. (2010). Statistical Yearbook of Ho Chi Minh City. Ho Chi Minh City: Bureau of Statistics.

Huat, C. B. (2011). Singapore as Model: Planning Innovations, Knowledge Experts. In Worlding Cities: Asian Experiments and the Art of being Global, edited by Ananya Roy \& Aihwa Ong, 29-54. Malden: WileyBlackwell.

Kim, A. M. (2008). Learning to be Capitalists. New York: Oxford University Press.

Ly, P., Birkeland, J. \& Demirbilek, N. (2010). Towards Sustainable Housing for Vietnam. (paper presented at the 4th International Conference on Sustainability Engineering and Science, Auckland, New Zealand, November 30 - December 3, 2010).

McGee, T. G. (2009). Interrogating the production of urban space in China and Vietnam under market socialism. Asia Pacific Viewpoint, 50(2), 228-246.

Ngo, A. \& Huynh. D. (2010). Urban Development through Infrastructure Land-based Financing: Cases in Ho Chi Minh City. Fulbright Economic Teaching Program.

O'Sullivan, D. \& Unwin, D. J. (2010). Geographic Information Analysis. Hoboken: John Wiley \& Sons.

Percival, T. \& Waley, P. (2012). Articulating Intra-Asian Urbanism: The Production of Satellite Cities in Phnom Penh. Urban Studies, 49(13), 2873-2888.

Property Report, 'Ho Chi Minh.' http://www.property-report.com/country-info/vietnam/ho-chi-minh (accessed 1 September, 2012).

Shatkin, G. (2011). Planning Privatopolis: Representation and Contestation in the Development of Urban Integrated Mega-Projects. In Worlding Cities: Asian Experiments and the Art of being Global, edited by Ananya Roy \& Aihwa Ong, 29-54, Malden: Wiley-Blackwell.

Tan, D. P. \& Fukushima, S. (2010). Transformation of Socio-economic Structure of Ho Chi Minh City under the Doi-Moi Policy and the Accompanying Globalization Process. Meijo Asian Research Journal, 1(1), 3-16.

Vietpartners, 'BMI View on FDI Attractiveness of Vietnam in year 2011.' http://www.vietpartners.com/Statisticfdi.htm (accessed 1 September, 2012).

Vo, T. T. (2005). A Resilient and Creative Investor. In An article on the memoirs for Lawrence S. Ting. Internal document of Phu My Hung Corporation.

Waibel, M. (2004). 'The Development of Saigon South New Urban Area: A Sign of an Increasing Internationalization and Polarization in Vietnamese Society’, Pacific News, July/August, 2004 
Wei, Y.H.D., Leung, C.K., Li, W. \& Pan, R. (2008). Institutions, Location, and Networks of Multinational Enterprises in China: A Case Study of Hangzhou. Urban Geography, 29(7), 639-661.

Wei, Y.H.D., Luo, J. \& Zhou, Q. (2010). Location Decisions and Network Configurations of Foreign Investment in Urban China. The Professional Geographer, 62(2), 264-283.

World Bank. (2011). Vietnam Urbanization Review: Technical Assistance Report. Hanoi, World Bank. 


\section{Figures}

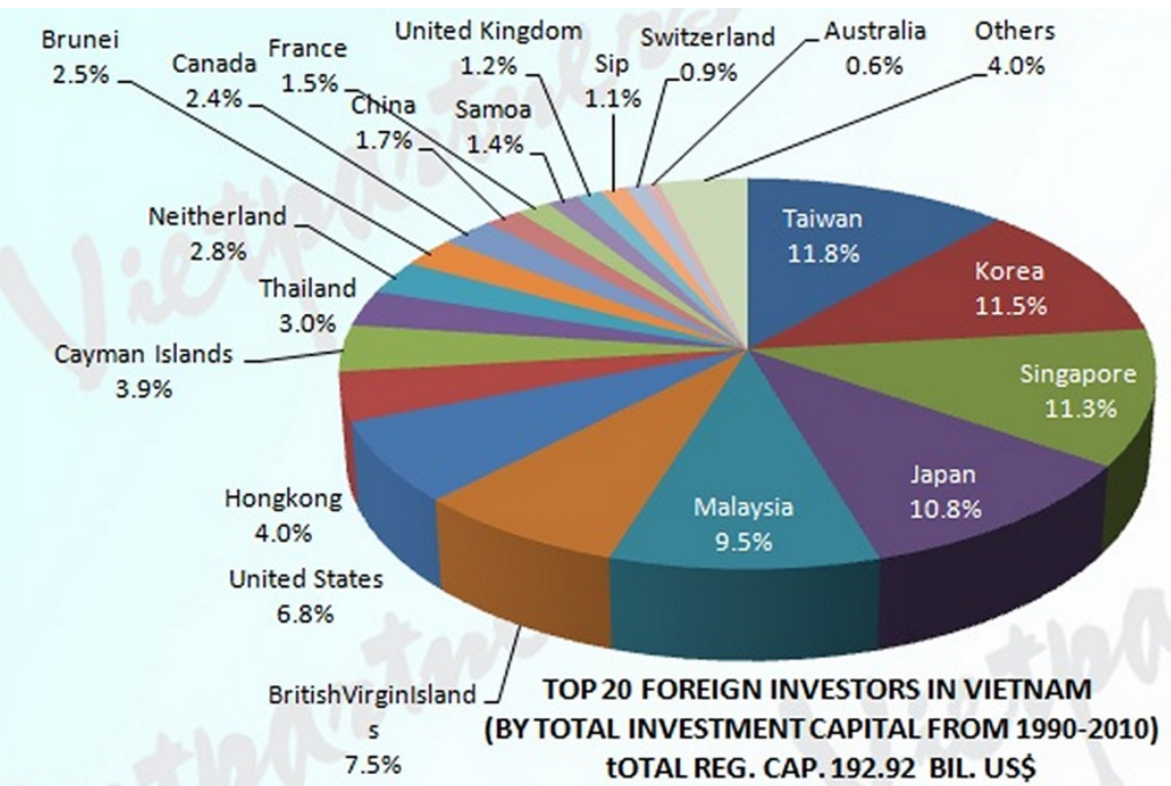

Fig. 1. Top 20 Foreign Investors in Vietnam

Source: http://www.vietpartners.com/Statistic-fdi.htm

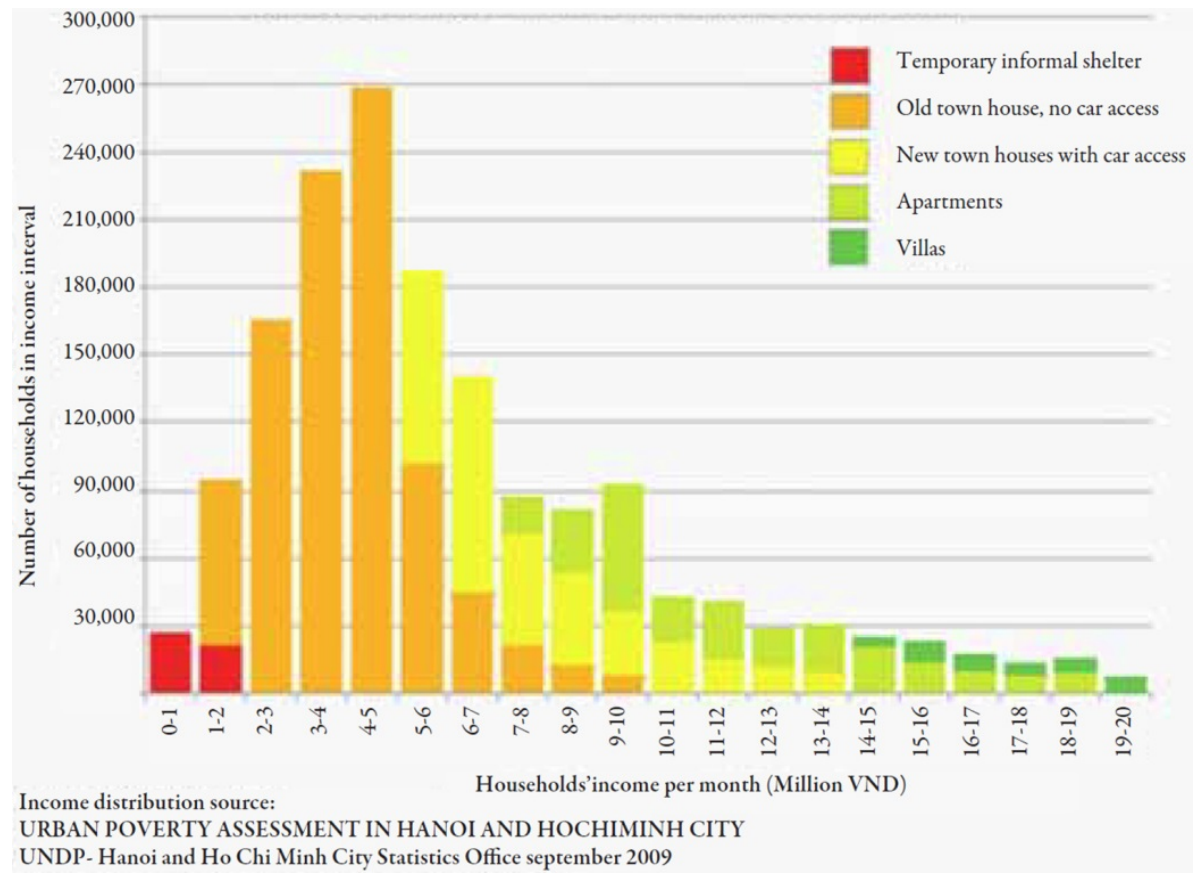

Fig. 2. Housing typology and household income in HCMC

Source: World Bank, 2011, 116 


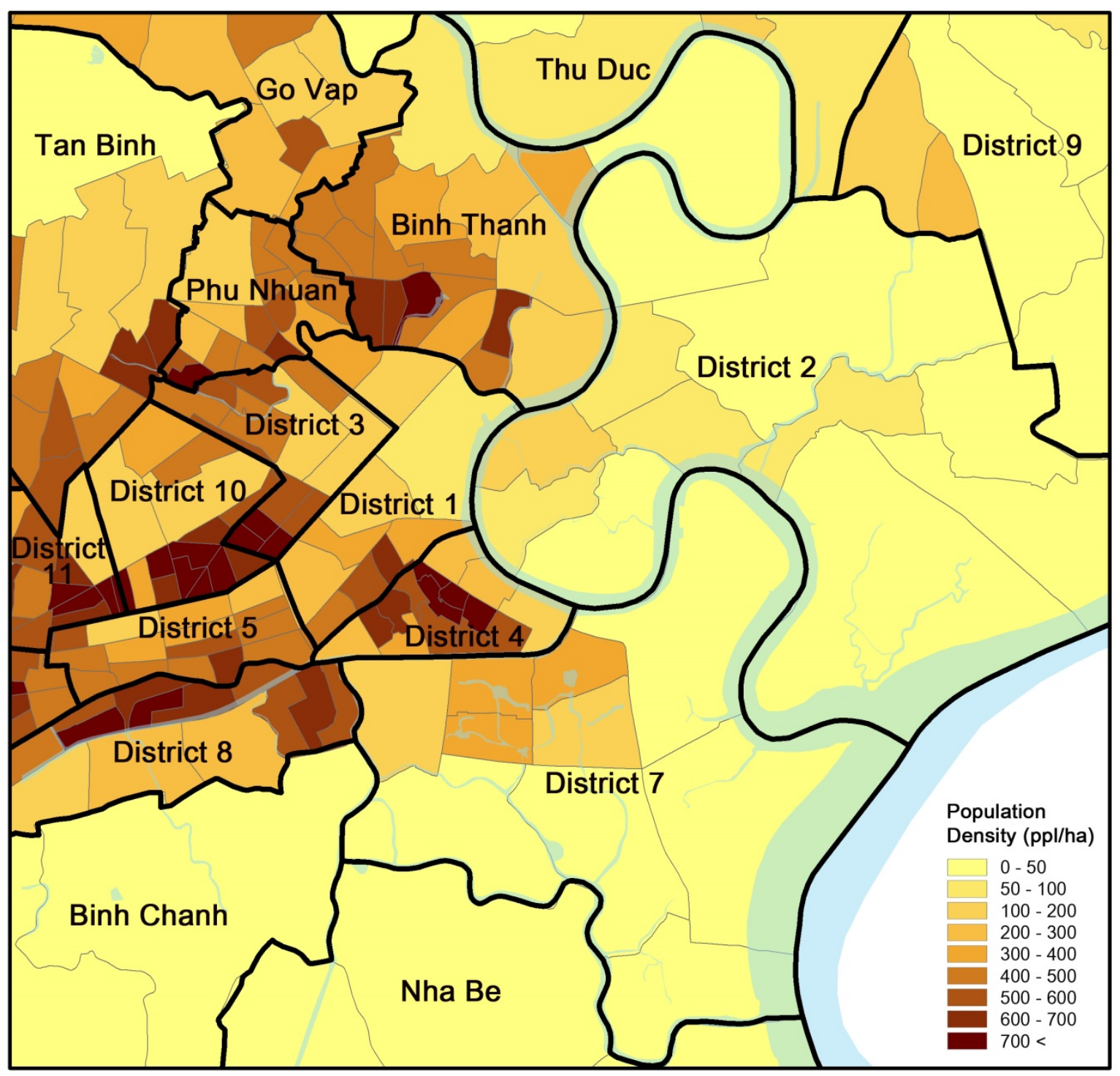

Fig. 3. District Name and Population Density in 2009 of Ho Chi Minh City

Source: Drawn by the author based on Ho Chi Minh City. Department of Statistics, 2010 


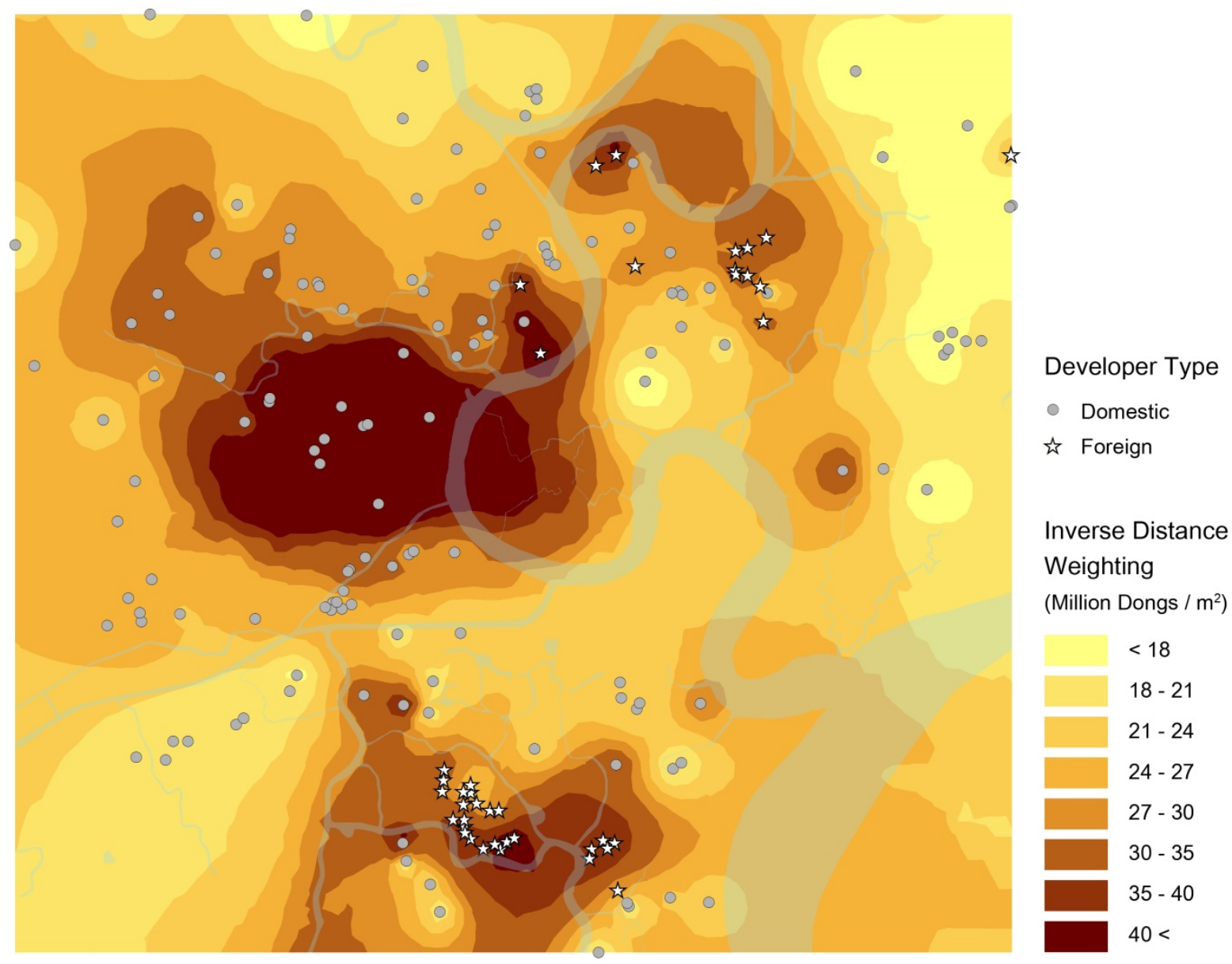

Fig. 4. Spatial Interpolation of Median Price per square meter and Developer Type Source: Drawn by the author 

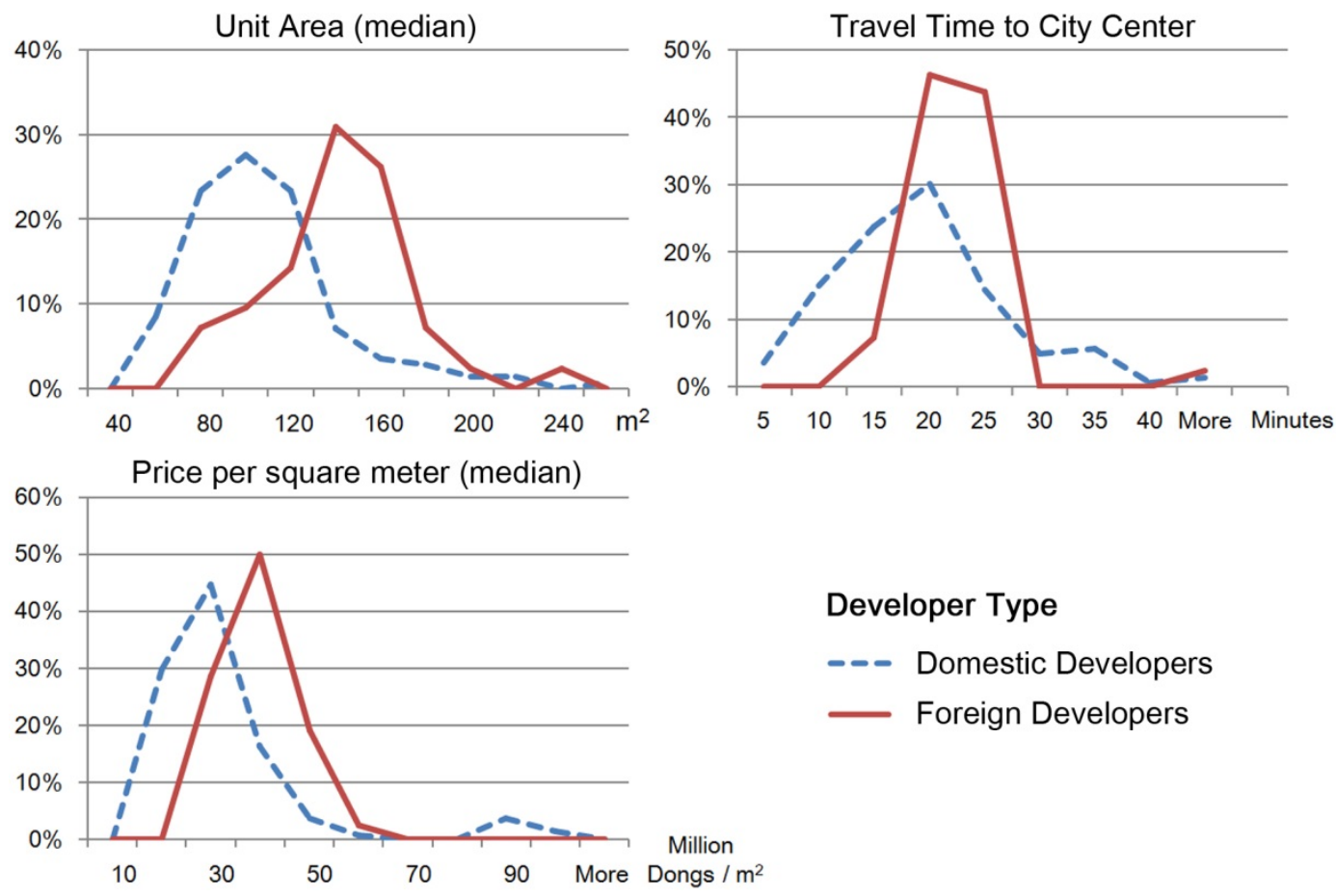

Developer Type

- - Domestic Developers

Foreign Developers

Fig. 5. Histogram of Unit Area, Travel time to City center and Price per sqm by foreign and domestic developers

Source: Drawn by the author
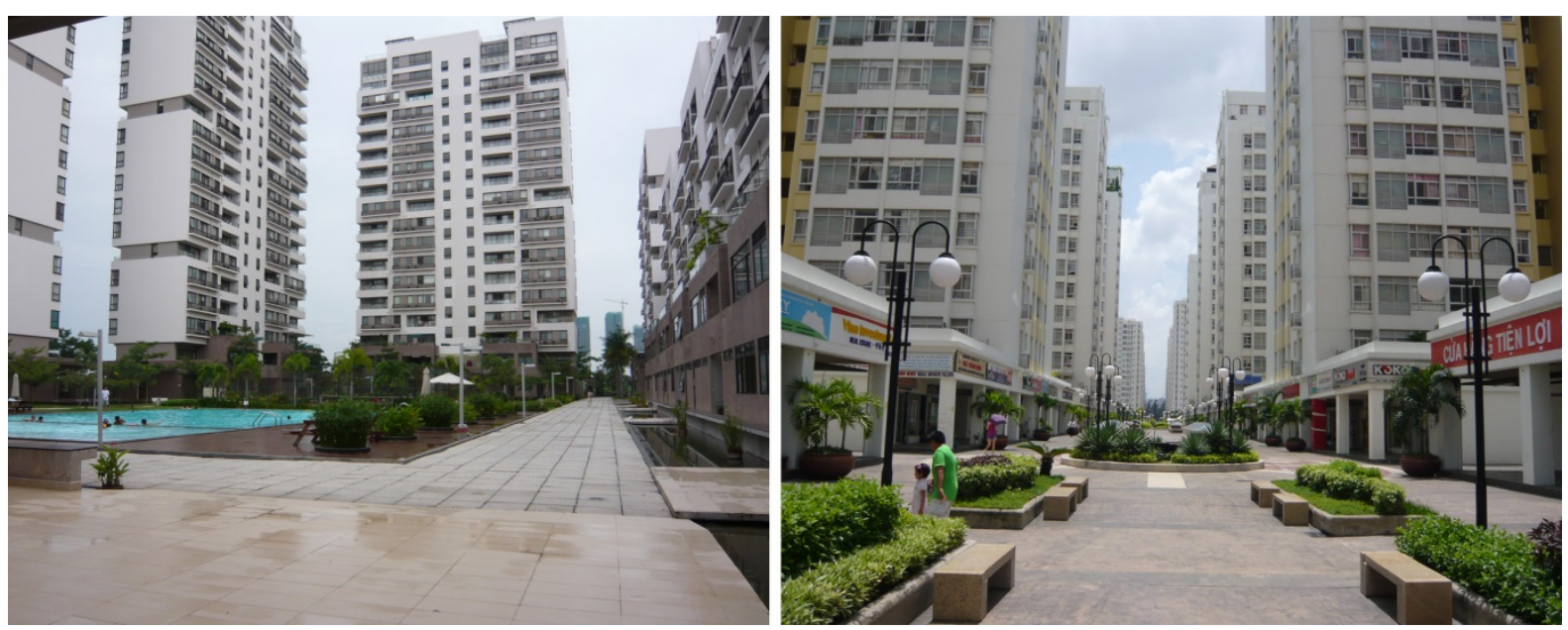

Fig. 6. Apartments developed by foreign joint ventures in PMH area Source: Photograph by the author 


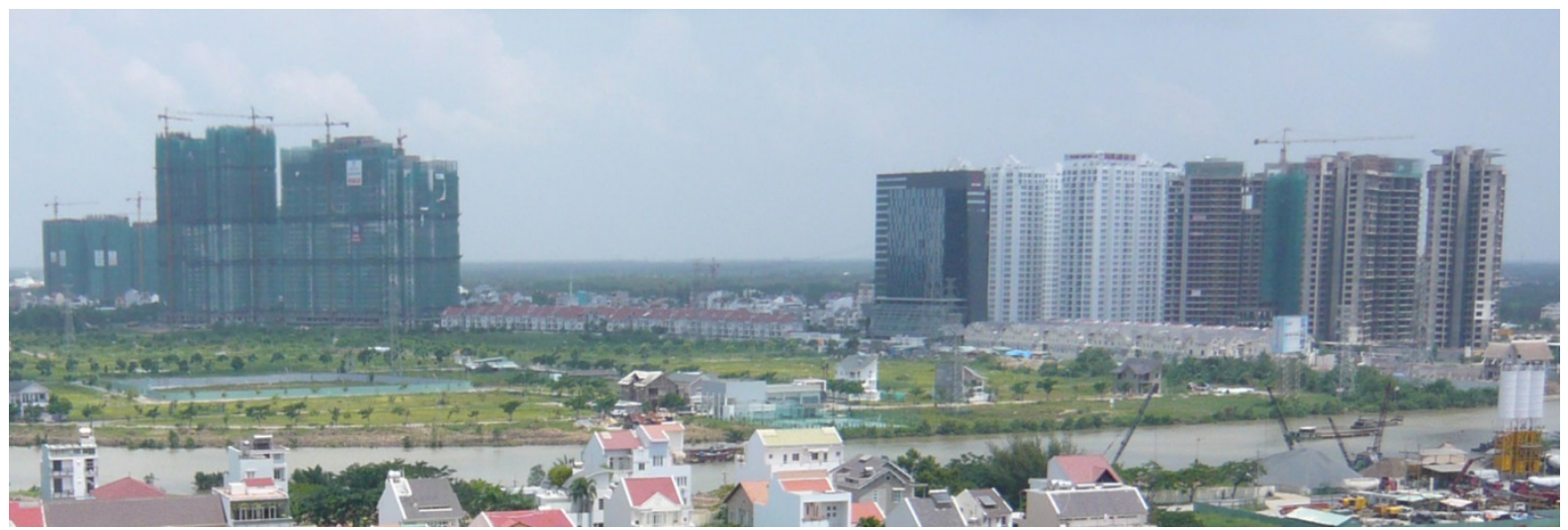

Fig. 7. Apartments developed by domestic developers in the vicinity of PMH area Source: Photograph by the author

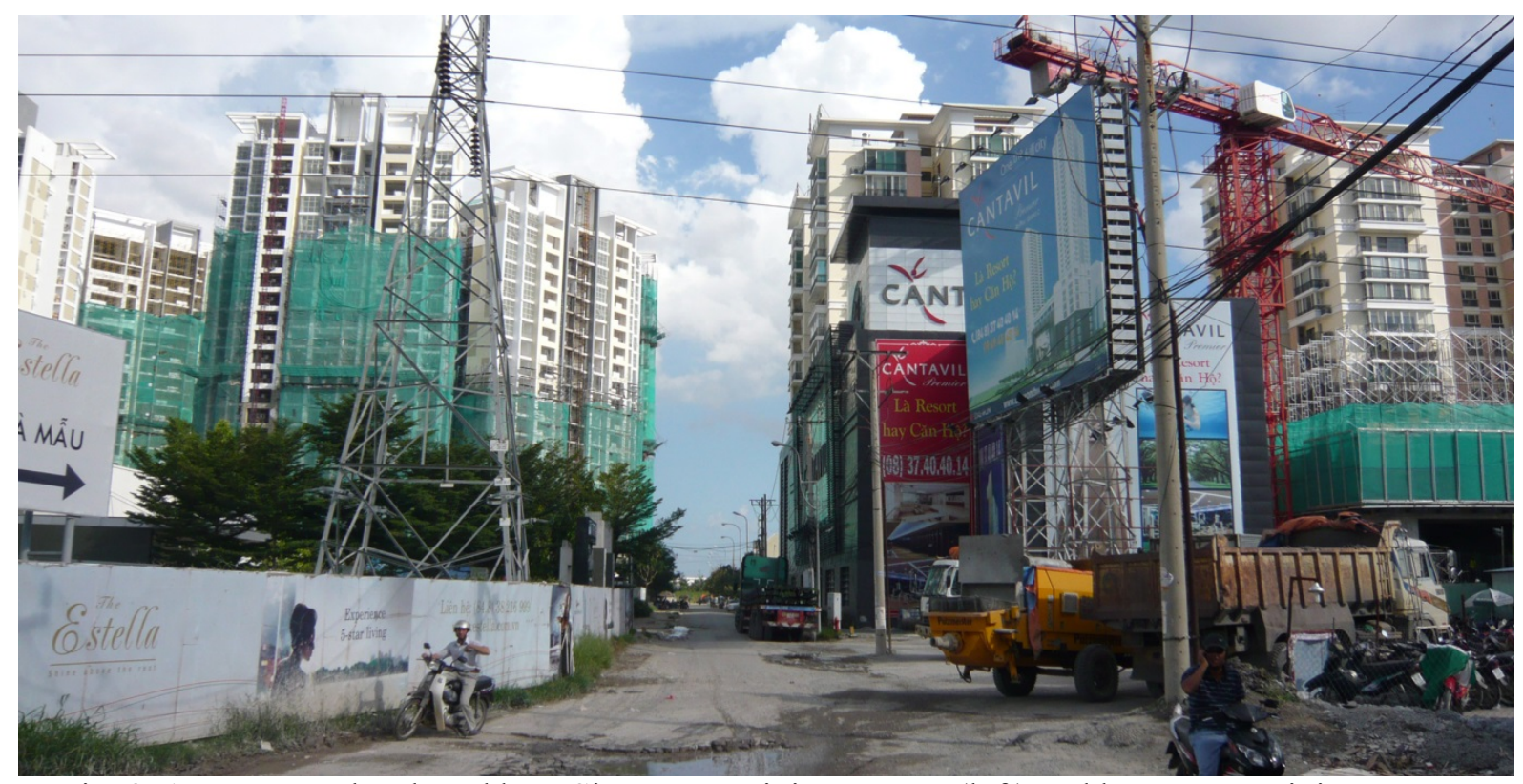

Fig. 8. Apartments developed by a Singaporean joint venture (left) and by a Korean joint venture (right)

Source: Photograph by the author 